\title{
The Effect of Service Quality and Customer Satisfaction on Customer Loyalty
}

\section{Rorim Panday \& M. Fadhli Nursal}

Management, Economic and Business Faculty, Bhayangkara Jakarta Raya University

\begin{abstract}
This study aims to know how service quality and customer satisfaction affect McDonald's customer loyalty. The object of this research is McDonald's fast food Restaurant. This type of research is quantitative and analysis techniques using multiple linear regression. The sample of this study was 210 respondents who were selected by the convenience sampling method. The results of this study are that Service Quality and Customer Satisfaction partially and simultaneously have a positive and significant effect on Customer Loyalty. Therefore, McDonald supposes that customers consider fast service, so they should minimize customer queues, to provide better price quotes to customers, and $\mathrm{Mc}$ Donald should continue to improve the quality of its services.
\end{abstract}

\section{Keywords:}

Service Quality, Customer Satisfaction, Customer Loyalty

\section{Corresponding Author:}

Rorim Panday

Fakultas Ekonomi , Universitas Bhayangkara Jakarta Raya

Jl. Raya Perjuangan, Marga Mulya, Bekasi Utara

Email: indripan@gmail.com

(C) The Author(s) 2021

DOI: https:// doi.org/ 10.36407/jmsab.v4i1.300

\section{Research Paper}

Management

Received: 26 Feb 2021

Accepted: 20 Jun 2021

Online: 28 Jun 2021

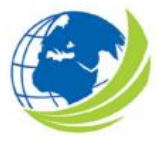

Jurnal Manajemen Strategi dan Aplikasi Bisnis, Vol 4, No. 1, 2021, pp. 171 - 180

eISSN 2655-237X

\section{(c) (1)}

CC BY: This license allows reusers to distribute, remix, adapt, and build upon the material in any medium or format, so long as attribution is given to the creator. The license allows for commercial use. 


\section{INTRODUCTION}

The business competition in the last decade has been very tight in line with the openness of the market for the business and service sectors. Facing these conditions, the Company uses various strategies to achieve specific segments and targets. Especially in the food business, so many businesses, ranging from small to large, are playing in its segment or trying to expand its segment. McDonald's is one fast food restaurant that serves various types of fast food. Food and drinks served are also very diverse such as burgers, fried chicken, and so on. Starting from a simple drive-in restaurant in Pasadena, McDonald's has grown into a fast-food restaurant franchise in almost every country (Sembiring, 2014). However, more and more fast-food restaurants are appearing to make competition harder. This condition makes McDonald's required to improve the quality of services provided to customers to impact the restaurant positively. The impact of customer satisfaction is the presence of high customer loyalty for the restaurant.

The changes in the environment and technology are also becoming increasingly rapid to support the competition (Panday, 2015). Companies have to do various ways to get new customers and keep customers from switching to other products. According to (Aryani et al., 2010a), one of the main objectives of marketing activities can be seen from the achievement of customer loyalty through marketing strategies. Moreover, customer loyalty has a good relationship with company performance (Lai et al., 2009). Customer loyalty not only increases value in business but can affect new customers(Lai et al., 2009).

Research on service quality on customer loyalty was conducted by (Gunawan et al., 2011) at a private-public hospital in Singaraja Bali. In this study, service quality was developed from the Servqual Parasuraman theory using five dimensions of service quality. Using multiple regression, then the five service quality variables simultaneously have a significant effect on customer loyalty. In the same vein, Hadiyati (2015) using five servqual variables in multiple regression. The results showed that all service quality variables had a significant effect on customer loyalty.

Research on service quality and customer satisfaction on loyalty was conducted by previous researchers (Dharmayanti, 2006; Fikri et al, 2016). In this case, service quality and customer satisfaction have a significant effect on customer loyalty. In addition, Dharmayanti (2006) confirms that service performance has a substantial direct influence on customer loyalty, and a good service performance does not always result in customer satisfaction. Furthermore, customer satisfaction as a moderating variable, it has been proven that customer satisfaction can moderate the effect of service performance on customer loyalty. (Aryani et al, 2010b) researched the effect of service quality on customer satisfaction in shaping customer loyalty at KFC. Using SEM from this study, the result is known that there is no influence between service quality and customer loyalty. Meanwhile, customer satisfaction on customer loyalty has a strong positive effect.

Customer satisfaction is the key to creating customer loyalty. The restaurant receives many benefits with a high level of customer satisfaction. In addition to increasing customer loyalty, customer satisfaction also prevents customer turnover, reduces customer sensitivity to prices, reduces marketing failure costs, reduces operating costs caused by increasing customer numbers, increases advertising effectiveness, and increases business reputation (Mudassar et al., 2013).

Good service is one way to influence customer interest. High-quality service is a weapon for fast food restaurants to remain standing and remain an option during intense competition. In 


\section{Rorim Panday \& M. Fadhli Nursal}

Service Quality, Customer Satisfaction, Customer Loyaltyi

addition to good service, efforts to improve the service quality system are also very much needed. The quality of service is far more effective for a business to run. This improvement effort will make customers more loyal to the restaurant. Based on the research that has been stated above, research will be carried out on the variables of service quality and customer satisfaction at the McDonald's restaurant on the customer loyalty variable. Therefore, problems at McDonald's, whether the level of service quality and customer satisfaction partially or together has a positive and significant effect on McDonald customer loyalty? Thus, the purpose of this study is to find out how the influence of the level of service quality and customer satisfaction on McDonald's customer loyalty in Bekasi. It is hoped that this research can provide benefits for McDonald's as input to the company's management.

\section{LITERATURE REVIEW}

\section{Customer loyalty}

Loyalty is a deep commitment of customers to customers coming back because of the quality of service, price, and good product quality (Widodo, 2016), and can be be measured by 3 indicators as follows (Kotler et al, 2012): loyalty to the product, loyalty to negative influences regarding the product, to fully reflect the company's existence.

\section{Service Quality}

Service quality is a form of consumer assessment of the level of service received at the expected level (De Barros Jerônimo et al, 2014;Parasuraman, 2010). While Parasuramanet al (1988) define service quality as customer perception of the service they receive. Besides, (Parasuraman et al, 1985) also stated that service quality is an aggregate evaluation of the service functions received in fact by the customer (technical quality) and how the service will be delivered (functional quality). If the service can be received and felt by consumers under consumer expectations, therefore the quality of the service can be considered good and vice versa if the quality of the service is not under consumer expectations, the quality of the service is not considered good by the view of consumers, because good and bad quality of service are seen from the customer benchmark not at the service provider. The quality of service is complex, which is explained that consumers will assess the quality of service through the five principles of service dimensions (Parasuraman et al., 1985). As a yardstick, that are:

1. Reliability: namely a design to carry out the promised service consistently, and reliably (accurately) according to ability.

2. Responsiveness: the willingness to respond quickly and responsively to customers

3. Assurance: encompasses the knowledge and friendliness of employees and their ability to create trust and confidence, courtesy, and trustworthiness that staff has, free from danger, risk, and doubt.

4. Empathy: understanding to devote attention to customers by providing guarantees of warranty in their products

5. Tangible: includes the physical appearance of products, facilities, product equipment, employees, and communication devices.

Some research on service quality has been carried out by (Panday, 2013) on train services, on service in the library by (Panday, 2016), at hotels industry by (Vatjanasaregagul et al., 2007), at 
Jurnal Manajemen Strategi dan Aplikasi Bisnis, Volume 4, Nomor. 1, 2021. 171-180

restaurants by (Karki, 2018;Sumaedi et al., 2015;Agnes Laurencia Setiawan, 2014), and at hospitals by (Punnakitikasemet al, 2012).

\section{Customer Satisfaction}

Customer satisfaction or often also called Total Customer Satisfaction is the level of customer feeling comparing between what is received and expected by the customer because it matches the expectations received based on the quality of a product and service provider that makes consumers feel more satisfied(Parasuraman, 2010). It can be said that customer satisfaction is quality. Likewise, a brief definition of quality is stated by (Rahmanet al, 2017) that quality is customer satisfaction. Quality of service is an important factor in attracting customers to become customers. (Rahman et al., 2017).There are several aspects of customer satisfaction, including product quality, price, service quality, emotional factors, and convenience. (Kotler et al., 2012; Sholihah et al., 2015; Sari et al., 2011).

1. Product quality dimensions. Product quality is one of the main factors of customer satisfaction. Product quality is a universal dimension consisting of 6 elements, namely performance, durability features, reliability, consistency, and design.

2. Price dimensions. Low prices are a source of customer satisfaction for sensitive customers because customers will get value for money. The price component becomes insignificant for those who do not see the product in terms of price but must be of good quality.

3. Service quality dimensions. Quality of service is a very important key to improve quality care in satisfying services. This concept of service quality is believed to have five dimensions: reliability, responsiveness, assurance, empathy, and tangibility.

4. Emotional dimension. When a customer will make a product purchase several emotional aesthetics, self-expressive value, and brand personality.

5. Dimensions of convenience. Consumers will feel satisfied, comfortable, and efficient in getting quality products and good service between employees and consumers.

\section{Hypothesis and Framework}

Service quality, customer satisfaction, and customer loyalty are variables phenomena that are widely discussed in many studies on many product objects in the form of goods and services. Good service will foster a sense of satisfaction to customers. Service is considered satisfactory if the service can meet the needs and expectations of consumers. The better the service, the more satisfied customers will be (Mosahab, 2010). This is confirmed by research (Syahir et al., 2014) and (Budiono et al., 2014). The more satisfied the customer, the greater the desire to use the product or service again (Budiono et al., 2014). It will repeat the use of the product/ service; Thus, the customer will not leave the product/service. Thus, customer loyalty arises in the products/ services (Budiono et al., 2014; Subagio, 2012).

Consumer loyalty can show how much support a consumer has for the products or services offered by the company. On the other hand, consumer loyalty can prove consumer confidence in the products or services provided by the company. Loyalty is a consumer's attachment to a particular product/ service due to psychological factors perceived from a quality product/ service or service quality(Kotler, 2000). So there is a relationship between product quality/ service quality with loyalty. Previous studies (Gunawan et al., 2011; Hadiyati, 2015) state that service quality affects customer loyalty. Thus, the hypothesis is:

H1 : Service Quality has a positive and significant effect on Customer Loyalty. 
Rorim Panday \& M. Fadhli Nursal

Service Quality, Customer Satisfaction, Customer Loyaltyi

In several studies, customer satisfaction is used as a mediating variable between service quality and customer loyalty, as done by (Agnes Laurencia Setiawan, 2014). However, several other researchers show there are an influence between customer satisfaction on customer loyalty, have been carried out by ( Fikri et al, 2016), ( Dharmayanti, 2006),and (Aryani et al, 2010). Then the research hypothesis is:

H2 : Customer Satisfaction has a positive and significant effect on Customer Loyalty.

Service quality and customer satisfaction are two things that foster customer loyalty (Kotler, 2000).Customers will be loyal to service quality or products quality. After the customer is satisfied, then there is a tendency for the customer to repeat the use of the product / service offered, which in the end the customer becomes loyal. Research that shows there is an effect of service quality and customer satisfaction on customer loyalty have been carried out by (Fikri et al, 2016). Then the research hypothesis is:

H3 : Service Quality and Customer Satisfaction simultaneously have a positive and significant effect on Customer Loyalty

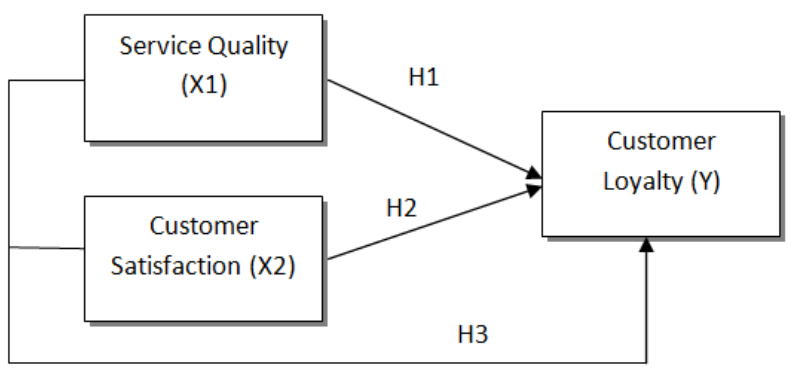

Figure 1.

Research Framework

\section{METHODOLOGY}

This type of research is quantitative by using specific samples for data collection, using research instruments, quantitative data analysis to test the hypotheses (Rorim, 2019; Sugiyono, 2010; Aruan et al., 2013). The location of this research was conducted at McDonald's Summarecon Bekasi branch. The sample used in this study was 210 respondents who were McDonald's consumers, which was determined by convenience sampling.

The data collection tool in this study was a questionnaire. The questionnaire contained statements distributed to consumers of McDonald's Summarecon Bekasi branch. The questionnaire processed using multiple regression analyses by SPSS software (Panday, 2019; Panday, 2001), included several tests: Validity Test, Reliability Test, F Test, Determinants Coefficient Test, and Partial t-Test.

There are three variables in this study, consisting of two independent variables and one dependent variable. These variables are the Service Quality variable as X1, the customer satisfaction variable as $\mathrm{X} 2$, and the customer loyalty variable as $\mathrm{Y}$. To measure these variables using a Likert scale (1 to 5). Responses ranged from 1 (strongly disagree) to 5 (strongly agree). The service quality variable is measured using five indicator items: tangible, reliability, responsiveness, assurance, and empathy. 
The customer satisfaction variable is calculated using five indicator items: Speed of service, service facility, staff friendliness, confirm expectations, and consumer dissatisfaction. And the last, the Customer loyalty variable is measured using five indicator items: make regular purchases, buy outside the product or service line, recommend to others, demonstrate immunity against the attraction of competitors, and comply with product us.

\section{RESULTS AND DISCUSSION}

Before doing the analysis, first, the reliability test of this research questionnaire was carried out. The reliability test used Cronbach Alpha. The Cronbach alpha value on the service quality variable is 0.770 . The Cronbach alpha value on the customer satisfaction variable is 0.721 . The Cronbach alpha value on the customer loyalty variable is 0.813 . According to the criteria, the Cronbach alpha value of the variable is $>0.70$. Then the questionnaire variables of service quality, customer satisfaction, and customer loyalty are distributed to have a good level of reliability.

Table 1.

Respondents profile

\begin{tabular}{lrr}
\hline Gender & Frequency & Percent \\
\hline Female & 140 & 66.7 \\
Male & 70 & 33.3 \\
\hline Total & 210 & 100 \\
\hline Age & & \\
\hline 17-21 year & 169 & 80.5 \\
22-26 year & 24 & 11.4 \\
27-31 year & 8 & 3.8 \\
>32 year & 9 & 4.3 \\
\hline Total & 210 & 100 \\
\hline Education & & \\
\hline Senior high school & 181 & 86.2 \\
Diploma & 7 & 3.3 \\
S1 & 19 & 9 \\
S2 & 3 & 1.4 \\
\hline Total & 210 & 100 \\
\hline Job & & \\
\hline Student & 157 & 74.8 \\
Entrepreneur & 17 & 8.1 \\
Private employees & 34 & 16.2 \\
Government & 2 & 1 \\
employees & 210 & 100 \\
\hline Total & & \\
\hline Income & 145 & 69 \\
\hline$<1$ million & 42 & 20 \\
2-4 million & 14 & 6.7 \\
5-7 million & 9 & 4.3 \\
\hline 10 million & 210 & 100 \\
\hline Total & & \\
\hline & & \\
\hline & & \\
\hline
\end{tabular}


Rorim Panday \& M. Fadhli Nursal

Service Quality, Customer Satisfaction, Customer Loyaltyi

\begin{tabular}{lrr}
\hline \hline Status & & \\
\hline Single & 192 & 91.4 \\
Married & 18 & 8.6 \\
\hline Total & 210 & 100 \\
\hline
\end{tabular}

Respondents consisted of 40 females (66.7\%) and 70 males (33.3\%). By age, respondents aged 17-21 years are the most respondents ( $80 \%)$. Based on the level of education, the most is high school education as many as 181 people $(86.2 \%)$, and the status as students $(74.8 \%)$, and 192 respondents $(81.4 \%)$ are unmarried people.

Tables 2

Descriptive Statistics

\begin{tabular}{lr|r|r|r|r}
\hline & N & Minimum & Maximum & Mean & $\begin{array}{c}\text { Std. } \\
\text { Deviation }\end{array}$ \\
\hline Servive Quality & 210 & 10 & 25 & 21.51 & 2.651 \\
\hline Customer Satisfaction & 210 & 9 & 25 & 21.14 & 2.641 \\
\hline Customer Loyalty & 210 & 8 & 25 & 19.64 & 2.825 \\
\hline Valid N (listwise) & 210 & & & & \\
\hline
\end{tabular}

The average value of the Service quality variable is 21.51 , with a standard deviation of 2.651 , a minimum value of 10 , and a maximum value of 25 . The average value of the Customer satisfaction variable is 21.14, with a standard deviation of 2.641, a minimum value of 9 , and a maximum value of 25 . The average value Customer loyalty variable is 19.64 , with a standard deviation of 2.825 , a minimum value of 8 , and a maximum value of 25 .

\section{Regression Analysis}

Table 3 results or F test can be assessed $F$ count $77,495>F$ table 3.04 with probability 0.0000 . Because the $p$-value $<0.05$, the model is declared to have fulfilled the goodness of fit.

Table 3.

Regression Analysis

\begin{tabular}{lcccc}
\hline & B & Beta & t & Sg. \\
\hline (Constant) & 3.553 & & 2.707 & 0.007 \\
Service quality & 0.271 & 0.254 & 3.519 & 0.001 \\
Customer satisfaction & 0.485 & 0.454 & 6.286 & 0.000 \\
& & & & \\
R & 0.654 & & & \\
Adj. R Square & 0.423 & & & \\
F-Statistics & 77.495 & & & \\
\hline
\end{tabular}

From the table above it can be seen that the resulting R-value is 0.654 meaning that the relationship between the independent variable and the dependent variable is strong. While the value of $\mathrm{R}$ square is 0.428 or $42.8 \%$, it means that the contribution of the independent variable, namely service quality, and customer satisfaction, is $42.8 \%$, while the remaining $57.2 \%$ is influenced by other variables outside this study. 
Jurnal Manajemen Strategi dan Aplikasi Bisnis, Volume 4, Nomor. 1, 2021. 171-180

The hypothesis partially t-test significance at table 3 that the service quality variable and customer satisfaction are supported ( $\mathrm{p}$-value $<0.05$ ).

\section{Discussion}

In this study, service quality affects customer loyalty. The results of this study are in line with the research that has been conducted by Gunawan et al. (2011) and Hadiyanti (2015). The results of other studies in line with Fikri et al. (2016) in the path model; meanwhile, with the research results by Aryani et al. (2010) in the SEM model, the results were inconsistent. Furthermore, the results of research where customer satisfaction affects customer loyalty are in line with the study conducted by Dharmayanti (2006), Fikri et al. (2016) in the path model, and Aryani et al. (2010) in the SEM model. At the same time, the results of research where service quality and customer satisfaction simultaneously affect loyalty are following previous studies (Dharmayanti, 2006; Fikri et al., 2016) in the path model and Aryani et al. (2010) in the SEM model. Thus the results of this study provide robust results. Therefore McDonald's restaurant can use the results of this study to maintain the quality of its service, customer satisfaction, and customer loyalty.

\section{CONCLUSION}

The object of this research is McDonald's fast food Restaurant. This type of research is quantitative and analysis techniques using multiple linear regression. The sample of this study was 210 respondents who were selected by the convenience sampling method. Based on the research results above, it can be concluded that Service quality partially has a positive and significant influence on customer loyalty to McDonald's. Customer satisfaction has a positive and significant effect on customer loyalty to McDonald's. Service quality and customer satisfaction together have a positive and significant impact on customer loyalty of McDonald's.

\section{Implications}

This study has practical implications: first, management needs to increase service speed by creating a system to minimize consumer queues. In addition, the management needs to reconsider the price strategy used by comparing the product prices with competitors' products. Second, management should continue to improve the quality of its services, both before and after the transaction. Customers become more satisfied and loyal to the company and do not hesitate to refer the company to its colleagues.

\section{Limitation and Suggestions}

This study has limitations on the use of the two variables studied and analytical techniques. Thus, future studies can consider other determinants of customer satisfaction and use more established analytical techniques such as SEM.

\section{REFERENCES}

Aryani, D., \& Rosinta, F. (2010). Pengaruh Kualitas Layanan terhadap Kepuasan Pelanggan dalam Membentuk Loyalitas Pelanggan. Bisnis \& Birokrasi, Jurnal Ilmu Administrasi Dan Organisasi, 17(2), 114-126.

Budiono, R., Sondang, Y., Si, S., Sc, M., Pemasaran, P. M., Petra, U. K., \& Siwalankerto, J. (2014). Pengaruh Service Quality Terhadap Loyalitas Pelanggan Dengan Customer Satisfaction Sebagai Variabel Intervening Pada Ritel Bioskop The Premiere Surabaya. Jurnal Manajemen Pemasaran Petra, 2(1), $1-7$. 


\section{Rorim Panday \& M. Fadhli Nursal}

Service Quality, Customer Satisfaction, Customer Loyaltyi

De Barros Jerônimo, T., \& Medeiros, D. (2014). Measuring quality service. International Journal of Quality \& Reliability Management. https:/ / doi.org/ 10.1108/ IJQRM-06-2012-0095

Diah Dharmayanti. (2006). Analisis Dampak Service PerforMance dan Kepuasan Sebagai MOderating Variable Terhadap Loyalitas Nasabah ( Studi pada Nasabah Tabungan Bank Mandiri Cabang Surabaya ). Jurnal Manajemen Pemasaran, 1(1), 35-43.

Gunawan, K., \& Djati, S. P. (2011). Kualitas Layanan dan Loyalitas Pasien (Studi pada Rumah Sakit Umum Swasta di Kota Singaraja-Bali). Jurnal Manajemen Dan Kewirausahaan, 13(1). https:/ / doi.org/ 10.9744/jmk.13.1.32-39

Hadiyati, E. (2015). Analisis Kualitas Pelayanan Dan Pengaruhnya Terhadap Loyalitas Pelanggan. Jurusan Manajemen Fakultas Ekonomi Universitas Jambi, 81-170.

Karki, D. (2018). How Food Quality , Price , Ambiance and Service Quality Effects Customer Satisfaction: A study on Nepalese Restaurants in. Haaga Helia, University of Applied sciences.

Kotler, P. (2000). Manajemen Pemasaran (Edisi Mile). Jakarta: Salemba Empat.

Kotler, P., \& Keller, K. L. (2012). Marketing Management, 14th Edition. Prentice Hall. https:/ / doi.org/ 10.1080/ 08911760903022556

Mosahab, R. (2010). Service Quality , Customer Satisfaction and Loyalty : A Test of Mediation, 3(4), 7280.

Panday, Rorim; (2016). Rediscovery Library Service Quality in Strengthening Quality Education Management. In Samolec.

Panday, Rorim. (2013). Service Quality Analysis of Argo Parahyangan Train As a Tool for Improving the Service. 11th INSYMA UBAYA, 978-979.

Parasuraman, A. (2010). Service productivity, quality and innovation: Implications for service-design practice and research. International Journal of Quality and Service Sciences, 2(3), 277-286. https:/ / doi.org/ 10.1108/17566691011090026

Parasuraman, A., Zeithaml, V. A., \& Berry, L. (1985). A conceptual model of service quality and its implications for future research. The Journal of Marketing, 49(4), 41-50. https:// doi.org/ 10.2307/ 1251430

Parasuraman, Zeithaml, V. A., \& Berry, L. L. (1988). SERVQUAL: a multiple-item scale for measuring consumer perceptions of service quality. Journal of Retailing, 64(1), 12-40. https:/ / doi.org/ 10.1016/ S0148-2963(99)00084-3

Punnakitikasem, P., Buavarapor, N., Maluesri, P., \& Leelartapin, K. (2012). Health Care Service Quality: Case Example of a Hospital with Lean Implementation. POMS 23 Rd Annual Conference, Chicago, Illinois, U.S.A April 20 to April 23, 2012, 2-6. Retrieved from http:/ / www.cmmu.mahidol.ac.th/ research/index.php/ conferences?view=publication\&task=sho w\&id=289

Rahman, M. S., Khan, A. H., \& Haque, M. (2017). A Conceptual Study on the Relationship between Service Quality towards Customer Satisfaction : Servqual and Gronroos's service Quality Model Perspective, 8(13), 201-210. https:/ / doi.org/ 10.5539/ ass.v8n13p201

Sari, W., Wibowo, L. A., \& Gitasiswhara. (2011). Analisis Service Experience Dalam menciptakan Kepuasan Penumpang Kereta Wisata PT. Kereta Api Pariwisata. Tourism and Hospitality Essentials (THE) Journal, I(10), 137-156.

Setiawan, A. L. (2014). Analisa Pengaruh Service Quality dan Customer Relationship Management terhadap Customer Loyalty dengan Customer Satisfaction sebagai variabel intervening di Kampoeng Kidz, Batu-Jawa Timur.Jurnal Strategi Pemasaran, 2(1), 1-9.

Sholihah, R. (2015). Pengaruh Kualitas Pelayanan Terhadap Kepuasan Pelanggan Kereta Api Ekonomi Jurusan Surabaya - Malang, 4.

Sirhan Fikri, Wahyu Wiyani, A. S. (2016). Pengaruh Kualitas Pelayanan Terhadap Kepuasan dan Loyalitas Mahasiswa (Studi pada Mahasiswa Strata I Fakultas Ilmu Sosial dan Ilmu PolitikUniversitas Merdeka Malang). Jurnal Bisnis Dan Manajemen, 3(1), 120-134.

Subagio, H. (2012). PENGARUH PERCEIVED SERVICE QUALITY , PERCEIVED VALUE , SATISFACTION DAN IMAGE TERHADAP CUSTOMER LOYALTY ( STUDI KASUS GARUDA INDONESIA ). Jurnal Manajemen Pemasaran, 7(1), 42-51. https:// doi.org/ 10.9744/ pemasaran.7.5.42-52

Sumaedi, S., \& Yarmen, M. (2015). Measuring Perceived Service Quality of Fast Food Restaurant in Islamic Country: a Conceptual Framework. Italian Oral Surgery, 3, 119-131. https:/ / doi.org/ 10.1016/ j.profoo.2015.01.012

Syahir, F., Quddus, A., \& Hudrasyah, H. (2014). THE INFLUENCE OF SERVICE QUALITY DIMENSIONS 
Jurnal Manajemen Strategi dan Aplikasi Bisnis, Volume 4, Nomor. 1, 2021. 171-180

ON CUSTOMER SATISFACTION AND CUSTOMER LOYALTY IN PT . JNE NORTH BANDUNG AREA, 3(5), 546-556.

Vatjanasaregagul, L., \& Thammathirat, S. (2007). The Impact Of Service Quality And Consumer Decision Factors On Brand Equity, 6(3).

\section{Competing interests}

The authors declare that they have no competing interests.

\section{Funding.}

The authors received no financial support for the research and publication of this article.

\section{About the Authors}

Dr. Rorim Panday, M.M., M.T. is a senior lecturer in production and operations management at the Faculty of Economics and Business, Bhayangkara University, Jakarta Raya. He holds a doctorate from De La Salle University, Manila, Philippines. He has researched various issues in production and operations management topics, especially those related to service quality and quality and has also been a speaker at various seminars, on production and operations management issues.

M. Fadhli Nursal, S.E., M.M. is a lecturer at the Faculty of Economics and Business, Bhayangkara University, Jakarta Raya, in the field of marketing management. 